\title{
The US Tomato Industry: An Overview of Production and Trade ${ }^{1}$
}

\author{
Zhengfei Guan, Trina Biswas, and Feng Wu²
}

\section{Introduction}

Tomatoes are one of the world's most consumed vegetable crops. According to statistics from the Food and Agriculture Organization (FAO), around 340 billion pounds (170 million tons) of fresh and processed tomatoes were produced globally in 2014 (FAO 2017). The harvested area covered 12.4 million acres (5 million hectares) of farmland. The world production of tomatoes has consistently increased since 2000, growing more than 54\% from 2000 to 2014 (FAO 2017). China is the largest producer of tomatoes, followed by the United States and India. Other major players in the tomato market are the European Union and Turkey. Together, these top five tomato producers supply around $70 \%$ of the global production. Mexico is the largest exporter of tomatoes in the world, followed by the Netherlands and Spain (CIA 2017). In 2016, Mexico, the Netherlands, and Spain accounted for 25.1\% (\$2.1 billion), $19 \%$ ( $\$ 1.6$ billion), and $12.6 \%$ ( $\$ 1.1$ billion) of the world's total tomato exports, respectively (CIA 2017).

In the United States, approximately 35 billion pounds (16 million tons) of tomatoes were produced in 2015; about $8 \%$ of the total production was fresh tomatoes, which have much higher prices than processed tomatoes. In 2015, the total values of fresh and processed tomatoes produced in the United States were $\$ 1.22$ billion and $\$ 1.39$ billion, respectively (USDA-AMS 2017). Florida and California account for about two-thirds of the national fresh tomato production (Wu, Guan, and Suh 2017), while California alone accounts for roughly $95 \%$ of the processed tomato

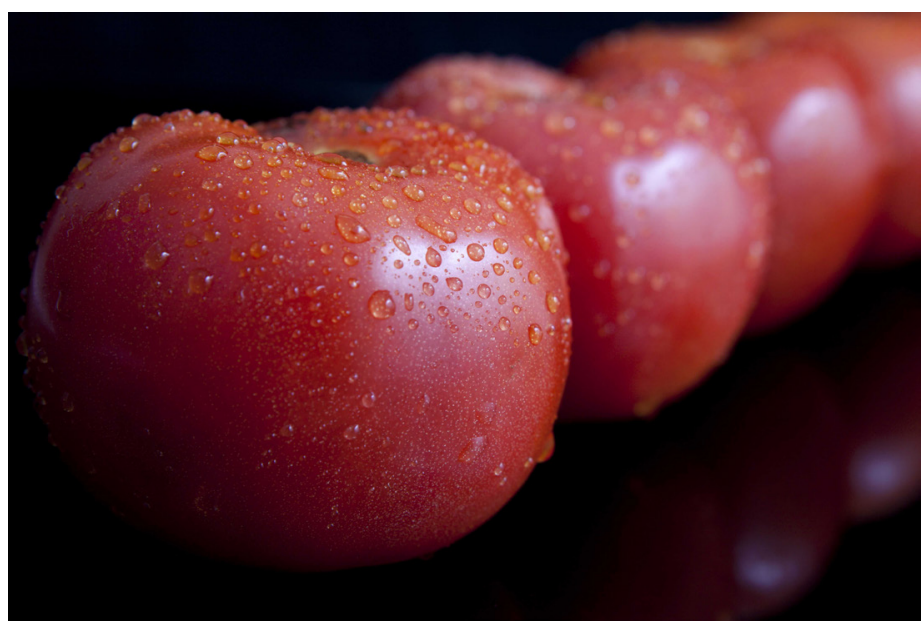

Credit: USDA

production (USDA-ERS 2017). This article focuses on fresh-market tomatoes.

\section{US Fresh Tomato Production}

The United States is one of the world's leaders in fresh tomato production. In 2015, 2.7 billion pounds of fresh tomatoes were produced in the United States. Domestic production accounts for about $40 \%$ of the total domestic demand for fresh-market tomatoes. The rest of the demand is met by imports, mostly from Mexico and Canada. Since 2000, fresh tomato production in the United States has exhibited a steady declining trend. Total US fresh tomato production dropped from 3.9 billion pounds in 2000 to 2.7 billion pounds in 2015 (Figure 1). One major reason is the increased competition from Mexico.

1. This is EDIS document FE1027, a publication of the Food and Resource Economics Department, UF/IFAS Extension. Published September 2017. Visit the EDIS website at http://edis.ifas.ufl.edu.

2. Zhengfei Guan, assistant professor; Trina Biswas, research associate; and Feng Wu, research assistant scientist; Food and Resource Economics Department, UF/IFAS Gulf Coast Research and Education Center, Balm, FL.

The Institute of Food and Agricultural Sciences (IFAS) is an Equal Opportunity Institution authorized to provide research, educational information and other services

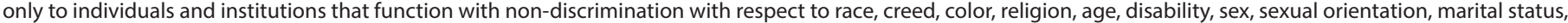

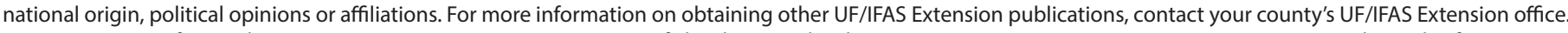
U.S. Department of Agriculture, UF/IFAS Extension Service, University of Florida, IFAS, Florida A \& M University Cooperative Extension Program, and Boards of County Commissioners Cooperating. Nick T. Place, dean for UF/IFAS Extension. 
Fresh tomatoes are produced nationwide in the United States, with California and Florida as the leading producers. In California, fresh tomatoes are produced year-round except in winter. In Florida, fresh tomatoes are produced from October to June, peaking in April-May and November-January (USDA-NASS 2016). Other top tomato-producing states (Georgia, North Carolina, Ohio, Tennessee, and Virginia) produce tomatoes in the summer months when Florida is out of the market.

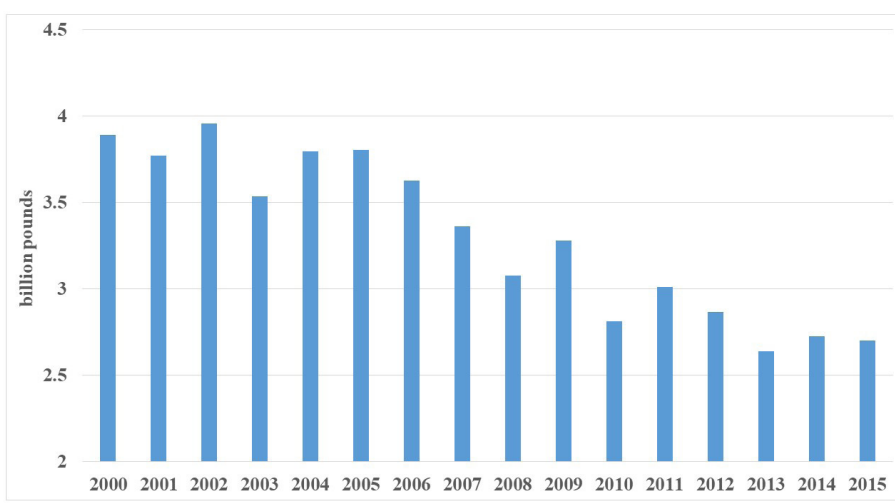

Figure 1. US tomato production, 2000-2015 (Source: USDA-NASS)

While Florida still ranks first in the nation in fresh tomato production, its production has experienced a steady decline since 2000. Production fell from 1.56 billion pounds in 2000 to 950 million pounds in 2015, dropping nearly $40 \%$ (Figure 2). The harvested acreage in Florida dropped from 39,400 acres in 2000 to 33,000 acres in 2015 (Figure $3)$. Florida had the highest yield among the top three tomato-producing states before 2009 ( $\mathrm{Zhu}$, Guan, and $\mathrm{Wu}$ 2013). In 2000, the average yield in Florida was roughly 40,000 pounds per acre, but by 2015 , yield had dropped to approximately 28,788 pounds per acre. The banning of the fumigant methyl bromide is one of the main reasons for the yield decline in Florida.

\section{US Fresh Tomato Prices}

Tomato prices have fluctuated over the years, showing an increasing trend before 2006 and afterward a large variation (Figure 4). The market price is mainly governed by market supply and demand. Changes in acreage and weather influence the market price of tomatoes by influencing the quantity supplied in the market. Tomato imports from Mexico also influence market price. On average, the price received for US fresh-market tomatoes in 2000 was around $\$ 30.7$ per cwt ( $1 \mathrm{cwt}=100$ pounds); the price increased to $\$ 40.7$ per cwt in 2016.

\section{US Fresh Tomato Trade}

Total US imports of tomatoes have risen consistently, from 1.61 billion pounds in 2000 to 3.66 billion pounds in 2016 (Figure 5). Net imports have shown a steadily increasing trend following the pattern of total imports. Net imports increased from 1.1 billion pounds in 2000 to 3.2 billion pounds in 2016 (Figure 5). In contrast, total US exports have stayed relatively steady, only dropping from 0.46 billion pounds in 2000 to 0.41 billion pounds in 2016 (Figure 5). In the NAFTA region, a major portion of US tomato exports goes to Canada, while only a small portion goes to Mexico.

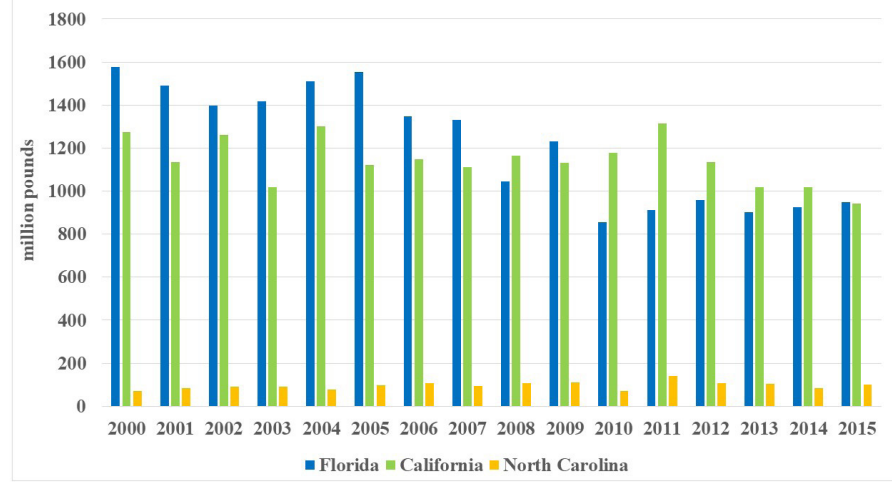

Figure 2. US production, three states, 2000-2015 (Source: USDANASS)

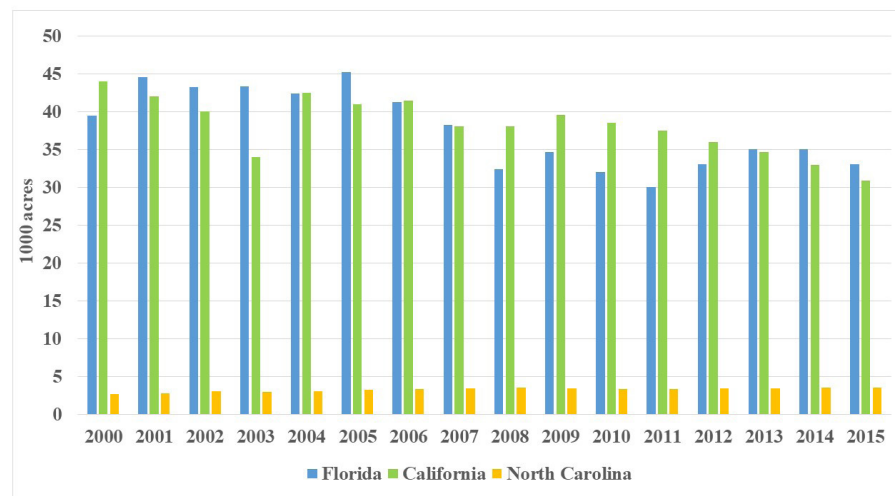

Figure 3. US acreage, three states, 2000-2015 (Source: USDA-NASS)

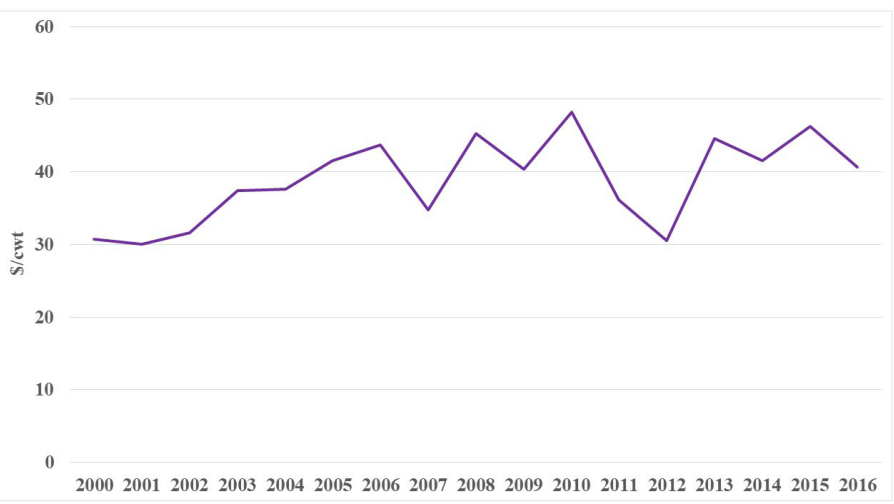

Figure 4. US fresh tomato prices, 2000-2016 (Source: USDA-NASS) 
Figure 6 shows the shares of different countries in US fresh market tomato imports. Mexico is the leading exporter of fresh tomatoes to the United States, followed by Canada. Imports of Mexican tomatoes have had a tremendous impact on the US tomato industry. Mexican imports accounted for $90 \%$ of the imported tomatoes in 2015 . The tomato import amount was more than three times greater than total Florida production. In contrast, the total share of Mexican tomatoes in the US market back in 2000 was about 20\% less than Florida's supply (Figure 7). Figure 7 shows the diverging trends of tomato production in Florida and imports from Mexico. Florida production fell from 1.5 billion pounds to 0.95 billion pounds from 2000 to 2015, while the imports from Mexico increased from 1.3 billion pounds to 3.1 billion over the same period.

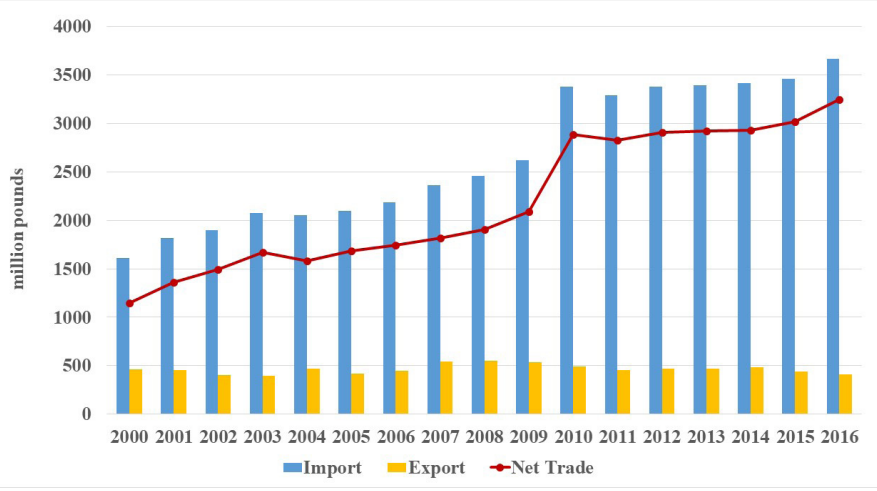

Figure 5. US fresh tomato trade, 2000-2016 (Source: USDOC)

Mexican producers have lower labor costs and more favorable government policies, which give them a competitive advantage over their US counterparts, leading to a consistent increase in Mexican production over the years. A labor cost analysis shows that the labor cost in Central Mexico was significantly lower than in Florida (Wu, Guan, and Garcia-Nazariega 2017). At the same time, the Mexican government has been encouraging adoption of the protected-culture technologies in the horticulture industry. According to a study by Victoria, van der Valk, and Elings (2011), the Ministry of Agriculture (Secretaría de Agricultura, Ganadería, desarrollo Rural, Pesca y Alimentación, or SAGARPA) provided 925.7 million Mexican pesos of subsidy for 1,220 hectares (3014.68 acres) of greenhouses between 2001 and 2006. The subsidy support was further increased in 2007 and 2008, with SAGARPA providing an additional 1,401.1 million Mexican pesos for 983 hectares of protected agriculture in 2007 and 420 hectares in 2008. In 2009, the Mexican government further introduced its Strategic Project for Protected Agriculture, which provided subsidies for various protected production practices, including greenhouses and high tunnels. Under this

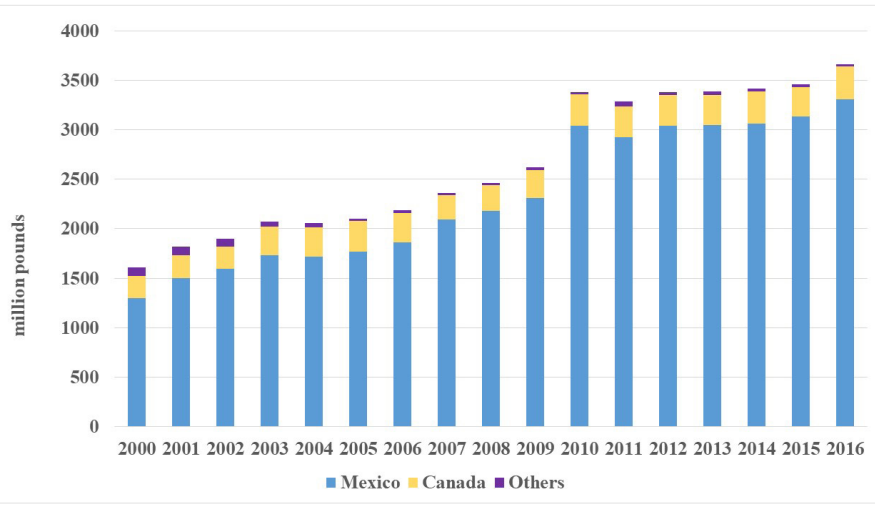

Figure 6. US fresh tomato imports (Source: USDOC)

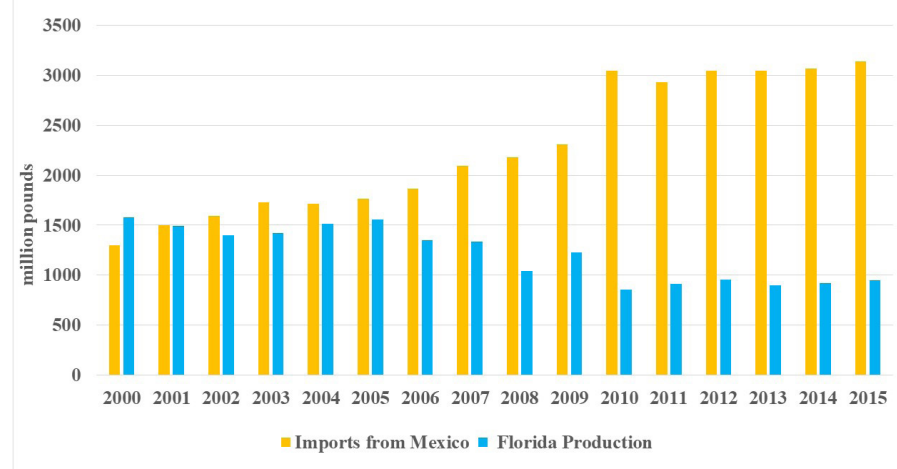

Figure 7. Florida production and Mexican imports, 2000-2015 (Source: USDOC)

program, subsidies were available for new installations, with up to $50 \%$ of the total costs, or a maximum amount set according to the type of technology. For example, the subsidy rate for high tunnels was set at 200,000 pesos per hectare, with a maximum amount of 1.5 million pesos per project, and for greenhouses 1.2 million pesos per hectare, with a maximum amount of 3 million pesos per project (Diario Oficial 2010; Victoria, van der Valk, and Elings 2011). Due to the favorable policies by the Mexican government, there was a large jump in protected acreage. In 2012, the protected acreage for tomatoes alone in Mexico was 34,595 acres (USDA-FAS 2013). Protected production technologies increase yields and give producers certain degrees of control over factors like weather and pests. It allows Mexican producers to supply products year-round to the US market by extending the regular growing season.

\section{Concluding Remarks}

Over the last few years, heavy competition with Mexico has resulted in a declining trend for US tomatoes. While NAFTA eliminated trade barriers and encouraged yearround imports from Mexico, Mexican government support and lower cost of production make Mexican tomatoes more competitive in the global market than US tomatoes. 
Increasing imports coupled with production issues at home such as labor shortages and the phase-out of methyl bromide have significantly affected the market share and profitability of US growers. The US government should take measures to help the domestic tomato industry resolve labor shortages and encourage research and development of labor-saving technologies such as mechanical harvesting to make the US tomato industry more competitive and sustainable.

\section{References}

CIA (Central Intelligence Agency). 2017. The World Factbook, Field Listing: Exports - Commodities. CIA, Washington, DC. https://www.cia.gov/library/publications/ the-world-factbook/fields/2049.html

Diario Oficial, Quinta Sección, Secretaria de Agricultura, Ganadería, Desarrollo Rural, Pesca y Alimentacion (SAGARPA), 31 de Diciembre de 2010.

FAO (Food and Agriculture Organization of the United Nations). 2017. FAOSTAT Database. http://faostat3.fao.org/

US-DOC (United States Department of Commerce). 2017. DOC website. https://www.commerce.gov/.

USDA-AMS (United States Department of Agriculture, Agricultural Marketing Service). 2017. Fruits and Vegetables Market News. USDA-AMS, Washington, DC. http://www. ams.usda.gov/market-news/fruits-vegetables

USDA-AMS (United States Department of Agriculture, Agricultural Marketing Service). 2017. Tomatoes. USDA-AMS, Washington, DC. http://www.agmrc.org/ commodities-products/vegetables/tomatoes

USDA-ERS (United States Department of Agriculture, Economic Research Service). 2017. Tomatoes. USDA-ERS, Washington, DC. https://www.ers.usda.gov/topics/crops/ vegetables-pulses/tomatoes.aspx

USDA-FAS (United States Department of Agriculture, Foreign Agricultural Service). 2013. Tomato Suspension Agreement Key to Production and Trade Forecasts (GATS). USDA-FAS, Washington, DC. https://gain.fas.usda. gov/Recent\%20GAIN\%20Publications/Tomato\%20Annual_Mexico\%20City_Mexico_5-31-2013.pdf

USDA-NASS (United States Department of Agriculture, National Agricultural Statistics Service). 2016. Data and
Statistics. USDA-NASS, Washington, DC. https://www.nass. usda.gov/Data_and_Statistics/index.php

Victoria, N.G., O.M.C. van der Valk, and A. Elings. 2011. Mexican Protected Horticulture: Production and Market of Mexican Protected Horticulture Described and Analysed (No. 1126). Wageningen UR Greenhouse Horticulture/LEI, Wageningen, The Netherlands.

Wu, F., Z. Guan, and M. Garcia-Nazariega. 2017. Comparison of Labor Costs between Florida and Mexican Strawberry Industries. FE1023. Gainesville, FL: University of Florida, Institute of Food and Agricultural Sciences. http://edis.ifas. ufl.edu/fe1023.

Wu, F., Z. Guan, and D.H. Suh. 2018. "The Effects of Tomato Suspension Agreements on Market Price Dynamics and Farm Revenue." Applied Economic Perspectives and Policy. Forthcoming. https://doi.org/10.1093/aepp/ppx029

Zhu, M., Z. Guan, and F. Wu. 2013. "An Overview of the US Tomato Industry.” 2013 Tomato Institute Proceedings. 